\title{
Alaskan soil carbon stocks: spatial variability and dependence on environmental factors
}

\author{
U. Mishra ${ }^{1, *}$ and W. J. Riley* \\ ${ }^{1}$ Earth Sciences Division, Lawrence Berkeley National Laboratory, 1 Cyclotron Road, 50A4037 Berkeley, CA 94720, USA \\ *currently at: Environmental Science Division, Argonne National Laboratory, 9700 South Cass Ave, Bldg 240, \\ Argonne, IL 60439, USA
}

Correspondence to: U. Mishra (umishra@anl.gov)

Received: 9 March 2012 - Published in Biogeosciences Discuss.: 14 May 2012

Revised: 21 August 2012 - Accepted: 27 August 2012 - Published: 20 September 2012

\begin{abstract}
The direction and magnitude of soil organic carbon (SOC) changes in response to climate change depend on the spatial and vertical distributions of SOC. We estimated spatially resolved SOC stocks from surface to C horizon, distinguishing active-layer and permafrost-layer stocks, based on geospatial analysis of 472 soil profiles and spatially referenced environmental variables for Alaska. Total Alaska state-wide SOC stock was estimated to be $77 \mathrm{Pg}$, with $61 \%$ in the active-layer, $27 \%$ in permafrost, and $12 \%$ in non-permafrost soils. Prediction accuracy was highest for the active-layer as demonstrated by highest ratio of performance to deviation (1.5). Large spatial variability was predicted, with whole-profile, active-layer, and permafrostlayer stocks ranging from $1-296 \mathrm{~kg} \mathrm{C} \mathrm{m}^{-2}, 2-166 \mathrm{~kg} \mathrm{~m}^{-2}$, and $0-232 \mathrm{~kg} \mathrm{~m}^{-2}$, respectively. Temperature and soil wetness were found to be primary controllers of whole-profile, active-layer, and permafrost-layer SOC stocks. Secondary controllers, in order of importance, were found to be land cover type, topographic attributes, and bedrock geology. The observed importance of soil wetness rather than precipitation on SOC stocks implies that the poor representation of high-latitude soil wetness in Earth system models may lead to large uncertainty in predicted SOC stocks under future climate change scenarios. Under strict caveats described in the text and assuming temperature changes from the A1B Intergovernmental Panel on Climate Change emissions scenario, our geospatial model indicates that the equilibrium average 2100 Alaska active-layer depth could deepen by $11 \mathrm{~cm}$, resulting in a thawing of $13 \mathrm{PgC}$ currently in permafrost. The equilibrium SOC loss associated with this warming would be highest under continuous permafrost (31\%), followed by dis-
\end{abstract}

continuous (28\%), isolated (24.3\%), and sporadic (23.6\%) permafrost areas. Our high-resolution mapping of soil carbon stock reveals the potential vulnerability of high-latitude soil carbon and can be used as a basis for future studies of anthropogenic and climatic perturbations.

\section{Introduction}

Soil organic carbon (SOC) can be a source or sink of atmospheric $\mathrm{CO}_{2}$, with the current balance depending on climate, disturbance, soil characteristics, and vegetation. Reliable estimates of regional SOC stocks and their spatial and temporal variability are essential to better understand controls of SOC stocks and their vulnerability to changing climate. Of particular concern are high-latitude SOC stocks, which are preserved, in large part, because of low temperatures. Highlatitude regions are expected to experience much higher temperature increases than temperate or tropical regions over the next century (IPCC, 2007) and therefore are a potentially vulnerable component of the global carbon cycle (Schuur et al., 2008; McGuire et al., 2009). Although uncertain, the total amount of frozen carbon in permafrost soils is estimated to be double (Schuur et al., 2009; Tarnocai et al., 2009) that currently in the atmosphere.

Several global SOC stock estimates exist for a variety of depth intervals (Post et al., 1982; Batjes, 1996; Jobbagy and Jackson, 2000). However, these global estimates substantially underestimate permafrost-affected SOC (Ping et al., 2008a; Tarnocai et al., 2009), mainly because of the paucity of high-latitude observations. Further, most of these 
studies limited the soil profile observations to the upper $1 \mathrm{~m}$ of soil profile even though high-latitude soils are reported to contain considerable deep SOC due to cryoturbation (Bockheim, 2007). Recent studies have also suggested the need for more accurate assessment of spatial heterogeneity of SOC stocks of permafrost-affected soils (Tarnocai et al., 2009; Johnson et al., 2011). To our knowledge, no regional highlatitude estimates exist of fine-resolution that shows spatial variability of SOC stocks in the whole-profile (O to C horizons), active-layer, and permafrost-layer.

Previous estimates of SOC stocks in permafrost-affected soils have been made by stratifying the study area, averaging point observations of SOC stocks within each stratum, and multiplying by the aerial extent of that stratum (Ping et al., 2008a; Tarnocai et al., 2009; Bliss and Maursetter, 2010; Johnson et al., 2011). Outside of permafrost areas, this approach has been reported to be associated with high estimation errors because it does not represent soil and environmental variable heterogeneity within each stratum (Thompson and Kolka, 2005; Meersmans et al., 2008; Sanchez et al., 2009). To address these concerns, McBratney et al. (2003) proposed a framework to predict the spatial distribution of SOC using spatially referenced "scorpan" factors (soil properties, climate, organisms, relief, parent material, age, and spatial coordinate). Several subsequent studies have demonstrated that this approach results in more accurate representation of spatial variability of soil properties and reduction of prediction errors (Thompson and Kolka, 2005; Rasmussen, 2006; Meersmans et al., 2008).

Spatially distributed observations of permafrost SOC stocks are important for development and testing of Earth system models (ESMs). Several recent modeling studies have integrated improved representation of high-latitude SOC dynamics (e.g., Lawrence et al., 2008; Schaeffer et al., 2011; Koven et al., 2011), but substantial differences remain between these ESM estimates and the coarse-resolution observationally based SOC estimates mentioned above. These differences occur because of uncertainties associated with spatially extrapolating limited observations and several limitations with the ESM modeling approaches, including lack of vertical resolution of SOC stocks, differing environmental controls of existing SOC stocks, unrealistic spatial representation to infer soil variability, and lack of pedogenic processes typical of high-latitude environments such as cryogenic aggregation, podzolization, and cryoturbation. Despite these limitations, ESMs are often used to predict carbonclimate feedbacks, although they predict very large ranges in permafrost SOC losses under future warming scenarios (25-85 Pg C) depending upon the processes included in the models (Koven et al., 2011).

Here, we used spatially referenced environmental variables (topographic attributes, land cover types, climate, and bedrock geology), and observed SOC pedon description data in a geographically weighted regression (GWR) approach to predict the spatial variability of SOC stocks and prediction accuracy throughout Alaska. Our approach allowed us to separately estimate active and permafrost-layer SOC stocks at $60 \mathrm{~m}$ spatial resolution, and to analyze the spatial variability under continuous, discontinuous, sporadic, and isolated permafrost regions. We also present predicted environmental controls on SOC stocks, and used them to estimate expected changes in equilibrium 2100 SOC stocks associated with the moderate A1B Intergovernmental Panel on Climate Change (IPCC) emissions scenario (IPCC, 2007).

\section{Materials and methods}

\subsection{SOC profile observations}

We used 422 geo-referenced SOC profile data from the National Soil Survey Characterization database (NSSL, 2010). This soil survey database includes measured representative soil profiles from Alaska and covered all soil types at the soil suborder level (18 suborders). We included additional 50 soil profile observations from the Arctic regions of North America (Ping et al., 2008a). Though the SOC profile samples were unevenly distributed throughout the study area (Fig. S1), the samples covered all 27 major land resource areas (MLRAs) of Alaska. The MLRA is a physiographic unit that contains similar patterns of climate, soils, water resources, and land uses (SCS, 1981). Since our objective was to estimate the SOC stock across Alaska, we included all the pedon description data in our study. Unfortunately, the majority of the pedon description data did not include bulk density (BD) observations. Therefore, the BD of each soil horizon was estimated using soil texture, depth, and organic matter content using pedotransfer functions developed by Calhoun et al. (2001) and Adams (1973). These functions have been widely used in literature to predict the soil BD for different soil types (all soil orders) across the globe (Post and Kwon, 2000; Tan et al., 2004; Minasny et al., 2006, 2011; Mishra et al., 2009, 2010). Since these relationships provide a general relationship to predict soil mineral BD from abovementioned soil properties and account for the amount of organic matter contribution in $\mathrm{BD}$, these equations can also be used to predict the BD of Gelisols. The SOC stock for each profile was estimated by summing the SOC stock from the surface to the $\mathrm{C}$ horizon:

$\mathrm{C}_{\mathrm{T}}=\sum_{j=1}^{n} \mathrm{C}_{j} \rho_{\mathrm{b}} D_{j}$

where $\mathrm{C}_{\mathrm{T}}=\mathrm{SOC}$ stock $\left(\mathrm{kg} \mathrm{m}^{-2}\right)$ of the whole soil profile, $j=$ soil horizon number $(1,2,3, \ldots, n), \mathrm{C}_{j}$ the SOC concentration $\left(\mathrm{kg} \mathrm{kg}^{-1}\right), \rho_{\mathrm{b}}$ the soil bulk density corrected for rock fragments $\left(\mathrm{kg} \mathrm{m}^{-3}\right)$, and $D_{j}$ the thickness of each horizon (m).

In the soil dataset, the presence of a permafrost layer was indicated by symbol $f$ (i.e., frozen layer). We used 
the average depth of the $f$ horizon to determine the boundary between permanently frozen and active layers. Table S1 shows the summary statistics of observed SOC stocks of whole-profile, active, and permafrost layers.

\subsection{Environmental datasets}

A digital elevation model (DEM) of $60 \mathrm{~m}$ spatial resolution was obtained from the USGS database (Multi-Resolution Land Characteristics Consortium, 2010). From the DEM we calculated 13 terrain attributes that are useful to predict the SOC stock across environmental conditions (using the spatial analyst function of ArcGIS version 10, Environmental Systems Research Institute, Inc., Redlands, CA, USA). These indices include elevation, slope, aspect, curvature (plan, profile, and total), upslope contributing area, flow length, soil wetness index, sediment transport index, stream power index, terrain characterization index, and slope aspect index. From the 13 topographic attributes, 4 attributes were selected for the model calibration in the best subset regression approach (Kutner et al., 2004). The included topographic attributes were elevation (meters), specific catchment area $\left(A_{\mathrm{s}}\right.$, $\mathrm{m}^{2} \mathrm{~m}^{-1}$ ), soil wetness index (SWI), and sediment transport index (STI). Specific catchment area is the upslope area per unit width of contour (Wilson and Gallant, 2000). The SWI indicates the spatial distribution and extent of zones of soil water saturation and is calculated as the ratio of specific catchment area to slope gradient ( $\beta$, degrees) (Wilson and Gallant, 2000):

$\mathrm{SWI}=\left(\frac{A_{\mathrm{s}}}{\tan \beta}\right)$.

The sediment transport index (STI) resembles the slopelength factor of the Universal Soil Loss Equation and characterizes erosional and depositional areas and potential erosion risk (Wilson and Gallant, 2000):

$\mathrm{STI}=\left(\frac{A_{\mathrm{s}}}{22.13}\right)^{0.6}\left(\frac{\sin \beta}{0.0896}\right)^{1.3}$.

Land cover data of 60-m spatial resolution were extracted for Alaska from the NLCD database (Multi-Resolution Land Characteristics Consortium, 2010). We reclassified the NLCD land cover types into 9 major categories (Table S2; Fig. S5). The largest land area was under the scrub category (43\%), followed by forest $(25 \%)$, barren $(8.5 \%)$, herbaceous $(7 \%)$, and wetlands $(7 \%)$. The remaining surface area $(9.5 \%)$ was under open water, perennial ice, barren land, and moss vegetation. Indicator variables for the presence or absence of 7 land cover types (except open water and perennial ice) were created and used in the model selection process.

The climate data, such as the long-term (1961-1990) mean annual air temperature and mean annual precipitation, were obtained from the PRISM database of spatial climate analysis service of the Oregon State University (Daly et al., 2001).
The bedrock geology data were obtained from a USGS database (Beikman, 1980). Across Alaska there were 180 types of bedrock. The largest land area was under Quaternary deposits $(8 \%)$, followed by Cretaceous rocks (7.3\%), Lower Paleozoic rocks $(6.6 \%)$, Lower Cretaceous rocks $(6.2 \%)$, ice $(4.3 \%)$, and Pleistocene deposits $(4.2 \%)$. The remaining surface area was under the remaining 174 bedrock types.

\subsection{Spatial modeling and accuracy of prediction}

We used a GWR approach (Fotheringham et al., 2002; Mishra et al., 2010; Zhang et al., 2011) and geospatial analysis to predict Alaska SOC stocks. First, the best subset regression was used to identify the environmental variables using a Mallows' $C_{p}$ criterion (Kutner et al., 2004). The model was tested for multicollinearity of selected independent variables, unequal error variance, normality, and randomness of the residuals. In this analysis, all the data points contributed to the estimates of model parameters equally using a least square solution. SAS statistical software (SAS, 2004) was used for model selection. The selected independent variables were then used in a GWR approach to derive the spatially varying model parameters at a $1000 \mathrm{~m}$ regular interval throughout the study area. In GWR, the weight function was chosen as an adaptive spatial kernel type so that the spatial extent for included samples varied based on sample density. The bandwidth was chosen based on Akaike information criterion minimization (Fotheringham et al., 2002). The GWR procedure can be represented as

$$
\begin{aligned}
\underset{i}{\operatorname{SOC}} & =\underset{0}{\hat{\beta}}\left(u_{i}, v_{i}\right)+\underset{1}{\hat{\beta}}\left(u_{i}, v_{i}\right) X_{i 1}+\underset{2}{\hat{\beta}}\left(u_{i}, v_{i}\right) X_{i 2} \\
& +\underset{k}{\hat{\beta}}\left(u_{i}, v_{i}\right) X_{i k}
\end{aligned}
$$

where $\underset{i}{\mathrm{SOC}}$ is the predicted SOC stock at location $i ;\left(u_{i}, v_{i}\right)$ are the coordinates for location $i ; k$ is the number of environmental variables; $\hat{\beta}-\hat{\beta}$ are regression coefficients; and $X_{i 1}$ to $X_{i k}$ are environmental variables at location $i$ (Table $\mathrm{S} 3$ and S4).

We evaluated the prediction accuracy of the resulting SOC stock maps by using a $K$-fold validation approach (Mishra et al., 2010; Martin et al., 2011). In this approach, the entire dataset was randomly divided into calibration $(n=412)$ and validation $(n=60)$ datasets five times. Mapping of SOC using calibration datasets and their validation were conducted for each split, and the average validation indices are reported here. From the predicted SOC maps, SOC stock values were extracted for the validation points. The obtained values of observed and predicted $\mathrm{C}$ pool were interpreted by calculating different validation indices, such as the mean estimation error (MEE) and root-mean-square error (RMSE):

$\mathrm{MEE}=\frac{1}{n} \sum_{i=1}^{n}\left(\mathrm{C}_{\mathrm{s}}\left(x_{i}\right)-\mathrm{C}_{\mathrm{s}}\left(x_{i}\right)\right)$ 
$\mathrm{RMSE}=\sqrt{\sum_{i=1}\left(\mathrm{C}_{\mathrm{S}}\left(x_{i}\right)-\mathrm{C}_{\mathrm{S}}\left(x_{i}\right)\right)^{2}}$

where $\mathrm{C}_{\mathrm{s}}\left(x_{i}\right)$ is the measured SOC stock, $\mathrm{C}_{\mathrm{s}}\left(x_{i}\right)$ the estimated SOC stock, and $n$ the number of validated observations. These values should approach zero for an optimal prediction. We also calculated the ratio of performance to deviation (RPD; defined as the ratio between the standard deviation and the RMSE), which indicates the overall prediction ability of the selected approach.

Environmental controls on SOC stocks were examined by converting temperature, precipitation, and elevation data into zones and then calculating the SOC stocks of active-layer, permafrost-layer, and whole-profile layers in each zone. Similar calculations were performed for land cover type impacts on SOC stocks. The impact of future warming on SOC stocks was evaluated using anticipated temperature changes under the moderate emission scenario (A1B) of IPCC. The downscaled future temperature change projections for Alaska were obtained from the Scenarios Network for Alaska Planning (SNAP, 2011). This dataset provides five model composite values (IPCC predictions: selected on the basis of smallest systematic errors) at a $2 \mathrm{~km}$ grid across Alaska. The dataset used to delineate continuous, discontinuous, isolated permafrost types was obtained from the permafrost map of Alaska (Ferrians, 1998).

\section{Results and discussion}

\subsection{Spatial and vertical distribution of soil organic carbon stocks}

In this section we discuss the predicted distribution of SOC stocks; estimates of the controls on SOC stocks are discussed in the following section. Predicted whole-profile SOC stocks had high spatial variability (coefficient of variability, $\mathrm{CV}=49 \%$ ), ranging from 1 to $296 \mathrm{~kg} \mathrm{~m}^{-2}$ with an average across Alaska of $53.6 \mathrm{~kg} \mathrm{~m}^{-2}$ (Fig. 1a). The northern and western regions of Alaska had the highest predicted levels of whole-profile SOC $\left(>75 \mathrm{~kg} \mathrm{~m}^{-2}\right.$ ) (Fig. 1a). The eastern and southern regions had the lowest whole-profile SOC stocks $\left(<50 \mathrm{~kg} \mathrm{~m}^{-2}\right)$. The average prediction error for whole-profile SOC stock was $26.3 \mathrm{~kg} \mathrm{~m}^{-2}$, and the observed ratio of performance to deviation (RPD) was 1.4, indicating our approach has a moderate predictive ability for wholeprofile SOC stocks (Gomez et al., 2008). The predicted average Alaska active-layer SOC stock was $35.4 \mathrm{~kg} \mathrm{~m}^{-2}$, ranging from 2 to $166 \mathrm{~kg} \mathrm{~m}^{-2}$ (Fig. 1b). Active-layer SOC stocks also had high spatial variability $(\mathrm{CV}=59 \%)$. The average error of prediction for active-layer SOC stock was $17.8 \mathrm{~kg} \mathrm{~m}^{-2}$, and the RPD was 1.5. Predicted permafrost SOC stock ranged from 0 to $232 \mathrm{~kg} \mathrm{~m}^{-2}$ with a spatial average of $21.3 \mathrm{~kg} \mathrm{~m}^{-2}$ and the highest spatial variability $(\mathrm{CV}=108 \%)$ (Fig. 1c). (a)

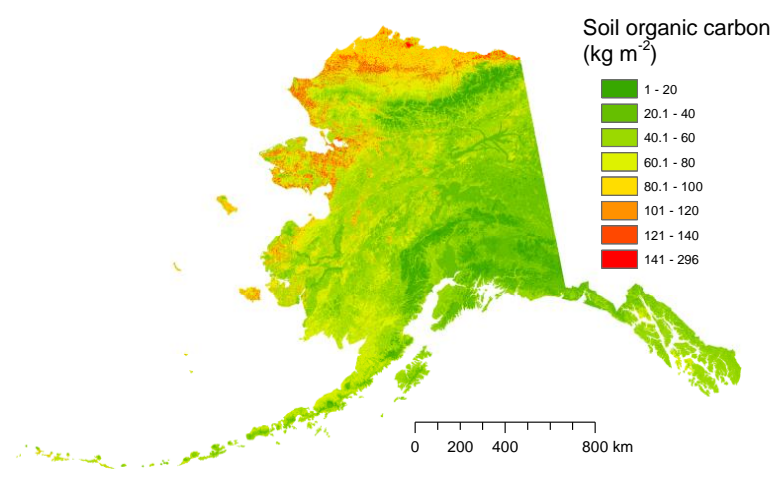

(b)

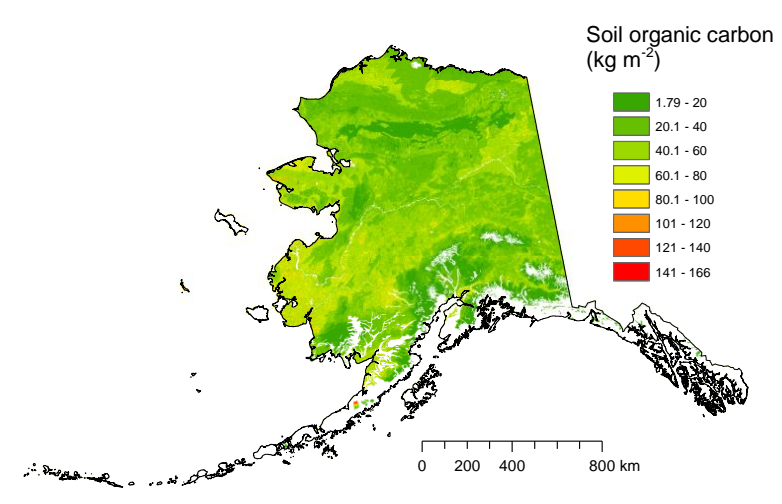

(c)

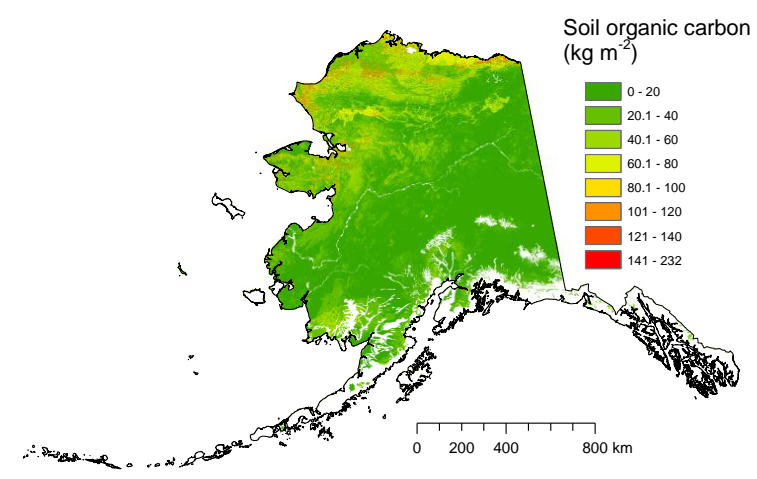

Fig. 1. Predicted soil organic carbon stocks in (a) whole-profile, (b) active-layer, and (c) permafrost layers in Alaska.

The observed average error of prediction was $36.6 \mathrm{~kg} \mathrm{~m}^{-2}$, and the RPD was 0.93 (Table 1). Our results suggest, on average across the state, a larger proportion of soil organic carbon is stored in the active-layer than in the permafrost layer of the permafrost-affected soils. Whole-profile SOC stocks across Alaska, excluding underneath water and glaciers, were estimated to be $77 \mathrm{Pg}$, of which $47 \mathrm{Pg}$ are in the active layer, $21 \mathrm{Pg}$ in the permafrost layer, and $9 \mathrm{Pg}$ in perennially unfrozen areas. Of the $21 \mathrm{Pg}$ permafrost SOC stock, 14, 5, 1, and $1 \mathrm{Pg}$ are under continuous, discontinuous, sporadic, and isolated permafrost areas, respectively (Table 2). 
Table 1. Prediction accuracy of soil organic carbon stocks of different depth intervals. MEE is mean estimation error; RMSE is rootmean-square error; RPD is ratio of performance to deviation.

\begin{tabular}{lrrr}
\hline $\begin{array}{l}\text { Soil organic carbon } \\
\text { stocks }\left(\mathrm{kg} \mathrm{m}^{-2}\right)\end{array}$ & MEE $\left(\mathrm{kg} \mathrm{m}^{-2}\right)$ & $\begin{array}{l}\text { Validation errors } \\
\text { RMSE }\left(\mathrm{kg} \mathrm{m}^{-2}\right)\end{array}$ & $\mathrm{RPD}$ \\
\hline Whole profile & -5.7 & 26.3 & 1.4 \\
Active layer & 3.2 & 17.8 & 1.5 \\
Permafrost & 11.2 & 37.6 & 0.9 \\
\hline
\end{tabular}

Our estimates of Alaska whole-profile SOC stocks are higher than previously published studies (Ping et al., 2008a; Tarnocai et al., 2009; Bliss and Maursetter, 2010; Johnson et al., 2011). Several factors contributed to the differences with these previous studies: we included more observations; our estimates were not limited to a relatively shallow depth inter$\mathrm{val}$; and we used a geospatial prediction approach that incorporates variability of environmental factors in predicted SOC stocks (McBratney et al., 2003; Thompson and Kolka, 2005; Meersmans et al., 2008; Sanchez et al., 2009). For comparison, Ping et al. (2008a) used 117 1-m deep samples from northern Alaska (north of $60^{\circ} \mathrm{N}$ ) and reported average SOC stocks to be $34.8 \mathrm{~kg} \mathrm{~m}^{-2}, 21.7 \mathrm{~kg} \mathrm{~m}^{-2}$, and $13.1 \mathrm{~kg} \mathrm{~m}^{-2}$ for $1 \mathrm{~m}$ depth, active, and permafrost layers, respectively (compared to our estimates which were 1.8, 1.5, and 2.3 times as large, respectively, for the same region). Though Ping et al. (2008a) were the first to report SOC stocks in different depth intervals from Arctic soils, they did not provide information about whole soil profile SOC stocks (down to C horizon). Tarnocai et al. (2009) used 131 observations from Alaskan soils and reported $18 \mathrm{Pg}$ of SOC stock to $3 \mathrm{~m}$ depth. However, this study did not differentiate the SOC stocks into active and permafrost layers and assigned no SOC to the nonpermafrost-affected soils of Alaska $\left(322629 \mathrm{~km}^{2}\right)$ where we predicted a range of $0-20 \mathrm{~kg} \mathrm{~m}^{-2}$ SOC. Bliss and Maursetter (2010) used 523 pedon data and STATSGO polygons (NRCS, 1994) to estimate the SOC stock of Alaska to be $48 \mathrm{Pg}$ (our estimate was 1.6 times as large). Finally, Johnson et al. (2011) stratified the state of Alaska into different ecoregions and reported area weighted average SOC stocks to $1 \mathrm{~m}$ depth of $45.7 \mathrm{~kg} \mathrm{~m}^{-2}, 16.3 \mathrm{~kg} \mathrm{~m}^{-2}, 22 \mathrm{~kg} \mathrm{~m}^{-2}$, and $24.6 \mathrm{~kg} \mathrm{~m}^{-2}$ for Arctic tundra, intermontane boreal, Alaska range transition, and coastal rainforests, respectively (our estimates were $1.5,3,1.6$, and 1.6 times as large when study area was stratified using the same ecoregions). For Arctic tundra, intermontane boreal, Alaska range transition, and coastal rainforests, the predicted coefficient of variability in whole profile SOC stock was $49 \%, 38 \%, 43 \%$, and $34 \%$, respectively. In the active layer SOC stock, the CV was $51 \%$, $33 \%, 82 \%$, and $221 \%$. In permafrost SOC stock, the observed CV was $78 \%, 145 \%, 111 \%$, and $140 \%$, respectively. Although these studies grouped regions differently and covered different areas of Alaska, our SOC stock estimates were between 1.3 and 3 times as large when comparable groupings were considered.

For comparison with whole-profile and permafrost-layer SOC stocks, we attribute differences between our results and these previous studies to the relatively deeper profiles we considered. Of the 472 SOC profiles we examined, 339 were non-permafrost-affected profiles; of these, $180(53 \%)$ were deeper than $1 \mathrm{~m}$. Of the remaining 133 permafrost-affected profiles, $76(57 \%)$ and $8(6 \%)$ were deeper than 1 and $3 \mathrm{~m}$ (up to $4.5 \mathrm{~m}$ ), respectively. Of the total samples, $126 \mathrm{sam}$ ples were deeper than $1.5 \mathrm{~m}$, of which 45 were in permafrostaffected soils. Because including these deeper profiles in our estimate led to substantially higher predicted whole-profile and permafrost-layer SOC stocks, we believe that these previous studies underestimated these portions of Alaskan SOC stocks. For active-layer SOC stocks, we attribute our $\sim 1.5$ times larger predictions to our geospatial non-stationary prediction approach, which considers the impact of the spatial heterogeneity of SOC controllers in contrast with these previous studies.

\subsection{Controls on soil organic carbon stocks}

We found that whole-profile, active-layer, and permafrost SOC stocks decreased with increased elevation (Fig. 2), and most SOC stocks $(70 \%)$ were located in areas with elevation below $400 \mathrm{~m}$. Low elevation areas throughout Alaska are associated with lower slope gradients and higher soil wetness, both of which were predictors of higher SOC stocks. This result is consistent with observations made by Ping et al. (2008a) who reported higher total SOC stocks in low elevation areas of Alaska north of $60^{\circ} \mathrm{N}$.

Annual average temperature was strongly related to activelayer and permafrost-layer SOC stocks: As the 30-yr annual average air temperature increased from -18 to $0^{\circ} \mathrm{C}$, active-layer SOC stock increased and permafrost-layer SOC stock decreased. Between 0 and $4^{\circ} \mathrm{C}$, the increase in predicted permafrost-layer SOC stock was due to inclusion of sporadic (14\% of Alaska surface area) and isolated (85\% of Alaska surface area) permafrost areas located in this temperature range. Both the active-layer and permafrost-layer SOC stocks decreased in the 4 to $6^{\circ} \mathrm{C}$ range. Whole-profile SOC stocks decreased with increased annual average temperature (Fig. S2). Our predicted control of temperature on the spatial distribution of whole-profile SOC stocks across Alaska is similar to the findings of other studies that reported negative relationships of air temperature to SOC stocks (Ping et al., 2008a; Johnson et al., 2011). The common explanation for this negative dependence is cryoturbation, i.e., subduction of surface SOC into the soil matrix due to seasonal freeze and thaw, and protection of this SOC from mineralization and decomposition due to freezing temperatures (Michaelson et al., 1996; Ping et al., 2008b).

Predicted whole-profile SOC stock decreased with increased precipitation up to $800 \mathrm{~mm}$ per year and then 


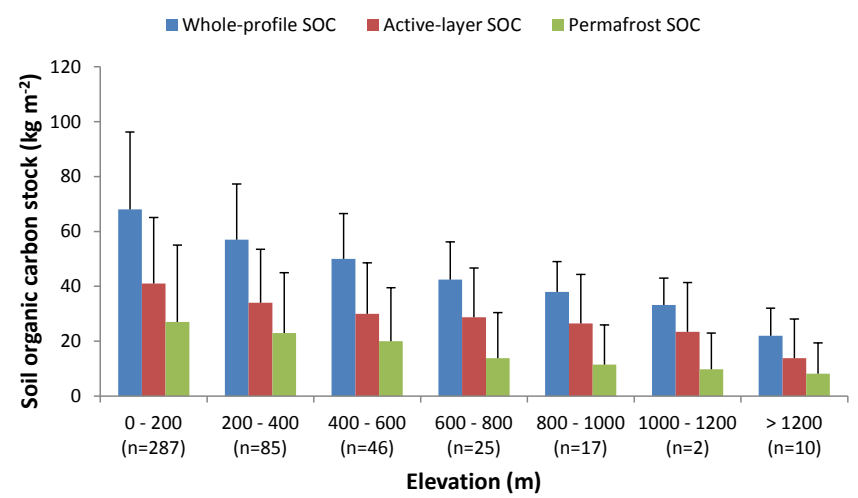

Fig. 2. Average whole-profile, active-layer, and permafrost SOC stocks in each elevation zone of Alaska. Error bar is the standard deviation and $n$ is the number of observations.

remained constant (Fig. S3). However, no trend was observed for active-layer and permafrost SOC stocks with precipitation. Our findings are consistent with observations reported by Guo et al. (2006) in the conterminous US, who also reported no consistent relationships with increasing precipitation. Since the dominant proximal hydrological control on SOC decomposition in upland systems is soil moisture and not directly precipitation, we used topographic wetness index as a soil moisture proxy in our spatial extrapolation approach. Predicted whole-profile and active-layer SOC stocks were strongly related to this index (Fig. S4). We believe that the observed importance of soil wetness rather than precipitation on SOC stocks implies that the poor representation of highlatitude soil wetness in Earth system models (Lawrence and Slater, 2005; Schaefer et al., 2011) may lead to large uncertainty in predicted SOC stocks under future climate change scenarios.

Among different land cover types, herbaceous vegetation had the highest Alaska-average whole-profile, active-layer, and permafrost SOC stocks (Fig. 3). After herbaceous vegetation, scrub and wetlands had the highest whole-profile SOC stocks. Barren land had the lowest predicted whole-profile, permafrost-layer, and active-layer SOC stocks in Alaska. These low stocks are likely due to low vegetation cover $(<15 \%)$, and therefore low productivity, and high-elevation and high-slope positions, and therefore high erosional losses.

\subsection{Impact of possible temperature changes on equilibrium Alaska carbon stocks}

Using the relationships we derived from the 472 pedons and controlling environmental variables described above, we estimated the equilibrium impact of anticipated temperature changes on SOC stocks and active layer thickness for the IPCC A1B 2100 climate. We note several important assumptions to this equilibrium SOC stock estimate: (1) current SOC stocks are related to the 30-yr average climate and current vegetation and soil distributions used to develop the spa-
Table 2. Soil organic carbon stocks in different depth intervals and permafrost zones across Alaska (NA = not applicable).

\begin{tabular}{lccc}
\hline $\begin{array}{l}\text { Permafrost } \\
\text { Category }\end{array}$ & $\begin{array}{c}\text { Whole Profile } \\
(\mathrm{Pg})\end{array}$ & $\begin{array}{c}\text { Active Layer } \\
(\mathrm{Pg})\end{array}$ & $\begin{array}{c}\text { Permafrost Layer } \\
(\mathrm{Pg})\end{array}$ \\
\hline Continuous & 32 & 18 & 14 \\
Discontinuous & 22 & 17 & 5 \\
Sporadic & 7 & 6 & 1 \\
Isolated & 7 & 6 & 1 \\
Unfrozen areas & 9 & $\mathrm{NA}$ & $\mathrm{NA}$ \\
\hline
\end{tabular}

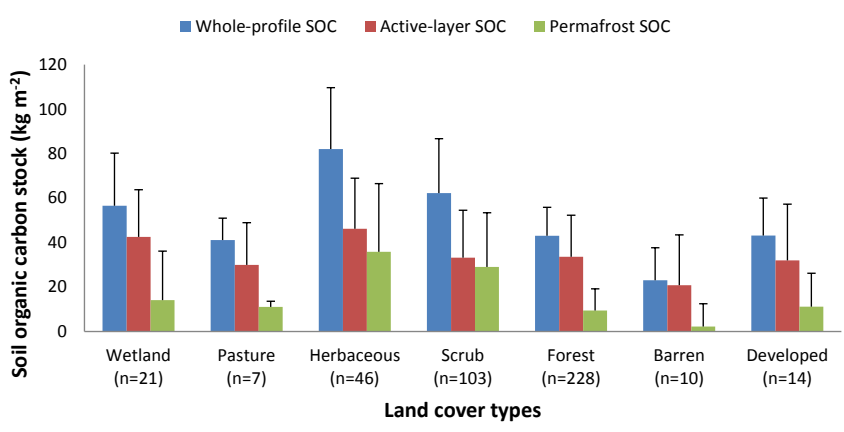

Fig. 3. Predicted average whole-profile, active-layer, and permafrost SOC stocks under different land covers in Alaska. Error bar is the standard deviation and $n$ is the number of observations.

tial extrapolation of individual pedons to all of Alaska as described above; (2) the estimated changes in SOC stocks reflect a new equilibrium state consistent with the new atmospheric temperature (i.e., SOC stocks have enough time to re-equilibrate with the new imposed climate, a process that can take many centuries); and (3) that interaction terms (e.g., between temperature, precipitation, vegetation distribution, and gross and net primary production) are neglected. Since none of these assumptions are likely to be fully realized, we consider the resulting estimates to be relatively uncertain. We note, however, that other methods used to predict changes in high-latitude SOC stocks under a changing climate, such as land-surface models integrated in global circulation models (Lawrence and Slater, 2010; Schaefer et al., 2011; Riley et al., 2011; Koven et al., 2011), come with their own equally restrictive, and occasionally acknowledged, assumptions. With these caveats in mind, and assuming an A1B IPCC temperature scenario at 2100, we estimated that the equilibrium Alaska-average active-layer thickness could deepen by $11 \mathrm{~cm}$, thawing $\sim 13 \mathrm{Pg}$ of permafrost SOC with an associated $27 \%$ loss of permafrost area throughout Alaska. The corresponding whole-profile permafrost SOC loss was estimated to be $31,28,24$, and $24 \%$ from continuous, discontinuous, isolated, and sporadic permafrost areas, respectively.

Modeling studies of permafrost loss and active layer thickness increases either for Alaska or for the Northern Hemisphere under the same emissions scenario (A1B) varied 
widely. For Northern Hemisphere permafrost area, Saito et al. (2007), Lawrence and Slater (2010), Lawrence et al. (2008), and Schaefer et al. (2011) predicted 40-57 \%, $73-$ $88 \%, 80-85 \%$, and $20-39 \%$ reductions, respectively. For Alaska, Marchenko et al. (2008) and Schaefer et al. (2011) predicted $7 \%$ and $22-61 \%$ permafrost area reduction, respectively. The projected range of increases in active-layer depth from these studies is also broad, ranging from 50$300 \mathrm{~cm}$. The large differences between these previous model projections are likely due to differences in model process representation, whether they included specific mechanisms (e.g., fire), climate forcing (e.g., snow and precipitation inputs, air temperatures), and the strength of land-atmosphere feedbacks. Direct comparisons with our results are complicated because these studies analyzed a larger region and attempted to include other factors that can impact permafrost SOC stocks, e.g., changes in hydrology, fire, growing season length, and others. Unfortunately, none of these numerical modeling studies reported results for simulations that can be directly compared to our estimates, which attempted to account for only the effects of changing temperature. Nevertheless, our predicted loss of permafrost area is at the lower end of the range of these studies, and our predicted increase in average active-layer thickness is lower than these previous estimates.

\subsection{Limitations of predicted SOC stocks}

Our prediction accuracy of current SOC stocks was constrained by the limited number of available SOC profile observations, their uneven distribution across Alaska, and variations in the time of observation (most of the samples were taken between 1975 and 1990). The current sample density of 1 sample per $2587 \mathrm{~km}^{2}$ area and their uneven distribution across Alaska is not sufficient to fully characterize SOC dependence on climate, edaphic factors, and land cover types. We believe that the SOC stock estimate will change, and probably increase, from our estimates if more samples are used, particularly from yedoma (loess deposits), and deltaic (alluvial deposits) soils that are several meters deep and store a huge amount of SOC. Likewise, we were not able to apply all relevant soil forming factors (environmental variables) since spatially resolved observations of, for example, fire frequency, fire intensity, and time of soil formation do not exist for much of Alaska. Future work should address the role these other factors have on high-latitude SOC stocks.

\section{Conclusions}

Our geospatial analysis using SOC profile observations and potential environmental and ecosystem controllers led to higher predicted Alaska SOC stocks than previously reported. We attribute the increase to our inclusion of deeper SOC profile observations, spatially heterogeneous environ- mental parameters, and non-stationary spatial modeling approach. Temperature and soil wetness were primary controllers on whole-profile, active-layer, and permafrost-layer SOC stocks. Secondary controllers, in order of importance, were land cover type, topographic attributes, and bedrock geology. The large spatial heterogeneity of these factors across Alaska led to very large predicted spatial variability in SOC stocks. We also estimated, with important caveats, potential equilibrium SOC losses associated with a moderate temperature change scenario (A1B). Our estimates of potential permafrost area loss and active-layer thickening were at the lower end of, and below, respectively, previously reported values from Earth system modeling analyses. Because of the caveats discussed above regarding the use of current observations to infer future conditions, analyses with mechanistic land-surface models are the only practical approach to accurately estimating future SOC stocks. However, since no current ESM accurately reproduces high-latitude SOC stocks, spatially distributed datasets based on observations, such as those reported here, are an important step toward improving and testing these models.

\section{Supplementary material related to this article is available online at: http://www.biogeosciences.net/9/ 3637/2012/bg-9-3637-2012-supplement.pdf.}

Acknowledgements. This study was supported by the Director, Office of Science, Office of Biological and Environmental Research, Climate and Environmental Science Division, of the US Department of Energy under Contract No. DE-AC02-05CH11231 to Berkeley Lab. Thanks to G. Michaelson and M. T. Jorgenson for providing access to some of the SOC profile data and layer of permafrost cover, respectively.

Edited by: P. Stoy

\section{References}

Adams, W. A.: The effect of organic matter on the bulk and true densities of some uncultivated podzolic soils, J. Soil Sci., 24, 1017, 1973.

Batjes, N. H.: Total carbon and nitrogen in the soils of the world, Eur. J. Soil Sci., 47, 151-163, 1996.

Beikman, H. M.: Geologic Map of Alaska, US Geological Survey, scale 1:2500000 (available at: http://agdc.usgs.gov/data/usgs/ geology/index.html), 1980.

Bliss, N. B. and Maursetter, J.: Soil organic carbon stocks in Alaska estimated with spatial and pedon data, Soil Sci. Soc. Am. J., 74, 565-579, 2010.

Bockheim, J. G.: Importance of cryoturbation in redistributing organic carbon in permafrost-affected soils, Soil Sci. Soc. Am. J., 71, 1335-1342, 2007. 
Calhoun, F. G., Smeck, N. E., Slater, B. K., Bigham, J. M., and Hall, G. F.: Predicting bulk density of Ohio soils from morphology, genetic principles, and laboratory characterization data, Soil Sci. Soc. Am. J., 65, 811-819, 2001.

Daly, C., Taylor, G. H., Gibson, W. P., Parzybok, T. W., Johnson, G. L., and Pasteris, P.: High quality spatial climate data sets for the United States and beyond, T. Am. Soc. Agr. Eng., 43, 19571962, 2001.

Ferrians, O. J.: Permafrost Map of Alaska, USA, Boulder, CO: National Snow and Ice Data Center/World Data Center for Glaciology, Digital Media, 1998.

Fotheringham, A. S., Brunsdon, C., and Charlton, M.: Geographically weighted regression the analysis of spatially varying relationships, John Wiley \& Sons, UK, 2002.

Gomez, C., Rossel, R. A. V., and McBratney, A. B.: Soil organic carbon prediction by hyperspectral remote sensing and field visNIR spectroscopy: An Australian case study, Geoderma, 146, 403-411, 2008.

Guo, Y., Gong, P., Amundson, R., and Yu, Q.: Analysis of factors controlling soil carbon in the conterminous United States, Soil Sci. Soc. Am. J., 70, 601-612, 2006.

IPCC: Summary for policy makers, in: Climate change 2007: The physical science basis, Contribution of Working Group 1 to the Fourth Assessment Report of the Intergovernmental Panel on Climate Change, edited by: Solomon, S., Qin, D., Manning, M., Chen, Z., Marquis, M., Averyt, K. B., Tignor, M., and Miller, H. L., Cambridge University Press, New York, 902-903, 2007.

Jobbagy, E. G. and Jackson, R. B.: The vertical distribution of soil organic carbon and its relation to climate and vegetation, Ecol. Appl., 10, 423-436, 2000.

Johnson, K. D., Harden, J., McGuire, A. D., Bliss, N. B., Bockheim, J. G., Clark, M., Nettleton-Hollingsworth, T., Jorgenson, M. T., Kane, E. S., Mack, M., O’Donnell, J., Ping, C., Schuur, E. A. G., Turetsky, M. R., and Valentine, D. W.: Soil carbon distribution in Alaska in relation to soil-forming factors, Geoderma, 167, 7184, 2011.

Koven, C. D., Ringeval, B., Friedlingstein, P., Ciais, P., Cadule, P., Khvorostyanov, D., Krinner, G., and Tarnocai, C.: Permafrost carbon-climate feedbacks accelerate global warming, P. Natl. Acad. Sci. USA, 108, 14769-14774, 2011.

Kutner, M. H., Nachtsheim, C. J., and Neter, J.: Applied linear regression models, McGraw-Hill, New York, 2004.

Lawrence, D. M. and Slater, A. G.: A projection of severe nearsurface permafrost degradation during the 21 st century, Geophys. Res. Lett., 32, L24401, doi:10.1029/2005GL025080, 2005.

Lawrence, D. M. and Slater, A. G.: The contribution of snow condition trends to future ground climate, Clim. Dynam., 34, 969-981, 2010.

Lawrence, D. M., Slater, A. G., Romanovsky, V. E., and Nicolsky, D. J.: Sensitivity of a model projection of near-surface permafrost degradation to soil column depth and representation of soil organic matter, J. Geophys. Res., 113, F02011, doi:10.1029/2007JF000883, 2008.

Marchenko, S., Romanovsky, V., and Tipenko, G.: Numerical modeling of spatial permafrost dynamics in Alaska, Proceedings Ninth International Conference on Permafrost, 2, 1125-1130, 2008.

Martin, M. P., Wattenbach, M., Smith, P., Meersmans, J., Jolivet, C., Boulonne, L., and Arrouays, D.: Spatial distribution of soil organic carbon stocks in France, Biogeosciences, 8, 1053-1065, doi:10.5194/bg-8-1053-2011, 2011.

McBratney, A. B., Mendonça-Santos, M. L., and Minasny, B.: On digital soil mapping, Geoderma, 117, 3-52, 2003.

McGuire, A. D., Anderson, L. G., Christensen, T. R. Dallimore, S., Guo, L., Hayes, D. J., Heimann, M., Lorenson, T. D., Robie, W., Macdonald, R. W., and Roulet, N.: Sensitivity of the carbon cycle in the Arctic to climate change, Ecol. Monogr., 79, 523-555, 2009.

Meersmans, J., De Ridder, F., Canters, F., De Baets, S., and Van Molle, M.: A multiple regression approach to assess the spatial distribution of soil organic carbon (SOC) at the regional scale (Flanders, Belgium), Geoderma, 143, 1-13, 2008.

Michaelson, G. J., Ping, C. L., and Kimble, J. M.: Carbon storage and distribution in tundra soils of arctic Alaska, USA, Arctic Alpine Res., 28, 414-424, 1996.

Minasny, B., McBratney, A. B., Mendonca-Santos, M. L., Odeh, I. O. A., and Guyon, B.: Prediction and digital mapping of soil carbon storage in the Lower Namoi Valley, Aust. J. Soil Res., 44, 233-244, 2006.

Minasny, B., Sulaeman, Y., and McBratney, A. B.: Is soil carbon disappearing? The dynamics of soil organic carbon in Java, Glob. Change Biol., 17, 1917-1924, 2011.

Mishra, U., Lal, R., Slater, B., Calhoun, F., Liu, D., and Van Meirvenne, M.: Predicting soil organic carbon stock using profile depth distribution functions and ordinary kriging, Soil Sci. Soc. Am. J., 73, 614-621, 2009.

Mishra, U., Lal, R., Liu, D., and Van Meirvenne, M.: Predicting the spatial variation of soil organic carbon pool at a regional scale, Soil Sci. Soc. Am. J., 74, 906-914, 2010.

Multi-Resolution Land Characteristics Consortium: National land cover database 2001, available at: www.epa.gov/mrlc/nlcd-2001. html, access: 3 April 2010, USEPA, Washington DC, 2010.

NRCS: State soil geographic (STATSGO) data base: Data use information, Misc. Publ. 1492, Natl. Cartogr. and GIS Ctr., Ft. Worth, TX, 1994.

National Soil Survey Laboratory: Soil characterization database, available at: http://ssldata.nrcs.usda.gov/, last access: 6 March 2010, 2010.

Ping, C. L., Michaelson, G. J., Jorgenson, M. T., Kimble, J. M., Epstein, H., Romanovsky, V. E., and Walker, D. A.: High stocks of soil organic carbon in the North American arctic region, Nature Geosci., 1, 615-619, 2008a.

Ping, C. L., Michaelson, G. J., Kimble, J. M., Romanovsky, V. E., Shur, Y. L., Swanson, D. K., and Walker, D. A.: Cryogenesis and soil formation along a bioclimate gradient in Arctic North America, J. Geophys. Res., 113, G03S12, doi:10.1029/2008JG000744, $2008 b$.

Post, W. M., Emanuel, W. R., Zinke, P. J., and Stangenberger, A. G.: Soil carbon pools and world life zones, Nature, 298, 156$159,1982$.

Post, M. and Kown, K. C.: Soil carbon sequestration and land-use change: processes and potential, Glob. Change Biol., 6, 317-327, 2000.

Rasmussen, C.: Distribution of soil organic and inorganic carbon pools by biome and soil taxa in Arizona, Soil Sci. Soc. Am. J., 70, 256-265, 2006.

Riley, W. J., Subin, Z. M., Lawrence, D. M., Swenson, S. C., Torn, M. S., Meng, L., Mahowald, N. M., and Hess, P.: Barriers to pre- 
dicting changes in global terrestrial methane fluxes: analyses using CLM4Me, a methane biogeochemistry model integrated in CESM, Biogeosciences, 8, 1925-1953, doi:10.5194/bg-8-19252011, 2011.

Saito, K., Kimoto, M., Zhang, T., Takata, K., and Emori, S.: Evaluating a high-resolution climate model: simulated hydrothermal regimes in frozen ground regions and their change under the global warming scenario, J. Geophys. Res., 112, F02S11, doi:10.1029/2006jf000577, 2007.

SAS Institute Inc.: Statistical analysis software version 9.1.3 for micro computers, SAS Institute Inc., NC, 2004.

Sanchez, P. A., Ahamed, S., Carre, F., Hartemink, A. E., Hempel, J., Huising, J., Lagacherie, P., McBratney, A. B., McKenzie, N. J., Mendonça-Santos, M. L., Minasny, B., Montanarella, L., Okoth, P., Palm, C. A., Sachs, J. D., Shepherd, K. D., Vågen, T., Vanlauwe, B., Walsh, M. G., Winowiecki, L. A., and Zhang, G. N.: Digital soil map of the world, Science, 325, 680-681, 2009.

Scenarios Network for Alaska planning: http://www.snap.uaf.edu, last access: 6 April 2010, 2011.

Schaefer, K., Zhang, T., Bruhwiler, L., and Barrett, A. P.: Amount and timing of permafrost carbon release in response to climate warming, Tellus, 63B, 165-180, 2011.

Schuur, E. A. G., Bockheim, J., Canadell, J. G., Euskirchen, E., Field, C. B., Goryachkin, S. V., Hagemann, S., Kuhry, P., Lafleur, P. M., Lee, H., Mazhitova, G., Nelson, F. E., Rinke, A., Romanovsky, V. E., Shiklomanov, N., Tarnocai, C., Venevsky, S., Vogel, J. G., and Zimov, S. A.: Vulnerability of permafrost carbon to climate change: Implications for the global carbon cycle, BioScience, 58, 701-714, 2008.
Schuur, E. A. G., Vogel, J. G., Crummer, K. G., Lee, H., Sickman, J. O., and Osterkamp, T. E.: The effect of permafrost thaw on old carbon release and net carbon exchange from tundra, Nature, 459, 556-559, 2009.

Soil Conservation Service: Land resource regions and major land resource areas of the United States, Agriculture Handbook 296, US Gov. Print. Office, Washington DC, 1981.

Tan, Z., Lal, R., Smeck, N. E., Calhoun, F. G., Slater, B. K., Parkinson, B., and Gehring, R. M.: Taxonomic and geographic distribution of soil organic carbon pools in Ohio, Soil Sci. Soc. Am. J., 68, 1896-1904, 2004.

Tarnocai, C., Canadell, J. G., Schuur, E. A. G., Kuhry, P., Mazhitova, G., and Zimov, S.: Soil organic carbon pools in the north circumpolar permafrost region, Global Biogeochem. Cy., 23, GB203, doi:10.1029/2008GB003327, 2009.

Thompson, J. A. and Kolka, R. K.: Soil carbon storage estimation in a forested watershed using quantitative soil landscape modeling, Soil Sci. Soc. Am. J., 69, 1086-1093, 2005.

Wilson, J. P. and Gallant, J. C. Digital terrain analysis, in: Terrain Analysis, edited by: Wilson, J. P. and Gallant, J. C., John Wiley and Sons, New York, 1-27, 2000.

Zhang, C., Tang, Y., Xu, X., and Kiely, G.: Towards spatial geochemical modeling: Use of geographically weighted regression for mapping soil organic carbon contents in Ireland, Appl. Geochem., 26, 1239-1248, doi:10.1016/j.apgeochem.2011.04.014, 2011. 